\title{
Protecting wildlife becomes endangered act
}

Washington. More than 20 years after becoming law, the US Endangered Species Act (ESA) faces major challenges in the Congress and Supreme Court that could severely limit its ability to protect threatened species. With the act scheduled for reauthorization this year, conservative Republicans in Congress have vowed to amend it to increase protection not of wildlife, but of private property owners.

Don Young (Republican, Alaska), chairman of the House of Representatives Resources Committee, plans to introduce an ESA reauthorization bill by early summer that will almost certainly call for landowners to be compensated by the government if their property loses value as the result of an endangered species listing. Opponents of the current law say that such losses amount to an illegal 'taking' of private property by the government.

Protection of property rights, and hostility toward federal regulations, are major themes for the new Republican majority, which last week pushed a measure through the House freezing most new federal rulemaking for the rest of this year - or until legislation overhauling the entire regulatory process is passed.

That process begins this week, when the House votes on a sweeping package that calls for 'takings' compensation, along with additional layers of review and risk assessment before any new federal rule is issued. Even if the Senate dilutes these bills, the takings issue is likely to surface with every environmental law that comes before Congress in the next two years.

Young has appointed a task force chaired by Richard Pombo, an arch-conservative Republican who is also a California rancher, to look into the reauthorization. The task force will hold public hearings beginning next month for citizens around the country. Similar hearings are planned by Dirk Kempthorne of Idaho, who chairs the equivalent Senate subcommittee.
All three congressmen have been vocal critics of the act, and the meetings are expected to provide a forum for landowners - primarily in Western states - to vent their anger at what they see as excessive federal regulation.

Meanwhile, bills have been introduced in both the House and Senate that would halt any new species listings or designation of

\section{IMAGE UNAVAILABLE FOR COPYRIGHT REASONS}

Under threat: the black bear is one species whose future is hanging in the balance

new critical habitat until the ESA is reauthorized. More than two dozen Republican Senators sent a letter in late January to chairman of the Senate environment committee, John Chafee of Rhode Island, pressing for early hearings on the bills.

In such a charged atmosphere, environmentalists and Democratic protectors of the ESA have been girding themselves for battle. But some moderates, such as Chafee, are searching for a middle ground. $\mathrm{He}$ and Bruce Babbitt, the Interior Secretary, have argued in recent weeks that property rights and protection of species are not mutually exclusive, and that claims of lost property value due to endangered species listings have been exaggerated. They concede, however, that the ESA does impose financial burdens in certain cases, and that the federal government could do a better job of easing

\section{French culinary secrets examined}

Paris. Not content with having a University of Oenology, in Bordeaux, for the study and application of 'wine science', France is now to create a European Centre for Taste Sciences at Dijon, home to the famous brand of mustard.

The idea of the centre has been cooked up by the food group Danone, the University of Burgundy, and the Centre National de la Recherche Scientifique (CNRS). Danone says it wants to create a "world-class" centre of research in a field with "considerable economic and social consequences".
Construction of the centre, which is expected to employ 80 staff, will begin this year. It will include an institute for fundamental research on taste, and a foundation designed to raise both awareness of and funds for taste research.

The creation of the centre's research recipes will be overseen by Styliano Nicolaidis, a CNRS researcher who works at the Collège de France in Paris. On the menu will be physiology, the modelling of olfaction, the neurophysiology of 'degustation' ('tasting'), and the social science of taste. Bon appetit! Declan Butler those burdens on small landowners.

With this in mind, the Interior Department recently introduced new policies designed to make it easier for property owners to comply with the act. For example, landowners with an endangered species on their property who agree to a long-term conservation plan will no longer be asked to commit more money or land at a later date if the needs of the species change.

The US Fish and Wildlife Service (FWS), which administers the act within the Department of Interior, has also requested additional money in 1996 to help states to develop habitat conservation plans. But these steps may not be enough to appease Republican critics, who have held up the ESA as one of their prime examples of intrusive government.

In attacking the current law, Republicans are also calling for more stringent scientific review of listing decisions for endangered species. "We need to bring sound science into the equation," says Kempthorne. "The listing of a species should be based solely on science."

But the FWS is already required to solicit extensive comment, including a recently instituted peer review by three outside scientists, for any listing decision. And even though many scientists say there are flaws in the current listing process - for example, its overemphasis on high-profile vertebrates the basic rationale is generally considered sound.

Environmentalists therefore charge that the demand for more review is simply a ploy to introduce delays or to allow non-scientists — including landowners - to influence the listing process. And they question why some Republicans want to strangle the fledgling National Biological Service (NBS), when that agency supplies the very scientific advice Kempthorne has requested. A House subcommittee last week voted to rescind \$17 million from the NBS, keeping the agency barely at maintenance level.

Budget cuts may in fact be the most effective way for Republicans to weaken the ESA even before it is reauthorized. The same House panel rescinded $\$ 2$ million from this year's FWS budget for listing new endangered species. That allows about 100 new listings this year - the minimum required to comply with a legal settlement stemming from a lawsuit by environmental groups. Some 170 listings had been planned in 1995.

As well as these attacks in Congress, the ESA faces one more hurdle this spring. The US Supreme Court has agreed to hear in April the case of Sweet Home Chapter of Communities for a Great Oregon v. Babbitt, which will determine whether the destruction of a species' habitat can be considered "harm" under the ESA. Tony Reichhardt 